Haya: The Saudi Journal of Life Sciences

Abbreviated Key Title: Haya Saudi J Life Sci

ISSN 2415-623X (Print) |ISSN 2415-6221 (Online)

Scholars Middle East Publishers, Dubai, United Arab Emirates

Journal homepage: https://saudijournals.com/sjls

Original Research Article

\title{
Agroforestry for Sustainable Agriculture in the Western Highlands of Cameroon
}

\author{
Abubakar Ali Shidiki ${ }^{1}$, Titus Fondo Ambebe ${ }^{2 *}$, Nyong Princely Awazi ${ }^{1}$ \\ ${ }^{1}$ Department of Forestry, Faculty of Agronomy and Agricultural Sciences, University of Dschang, Dschang, Cameroon \\ ${ }^{2}$ Department of Forestry and Wildlife Technology, College of Technology, The University of Bamenda, Bambili, Cameroon
}

DOI: $\underline{10.36348 / \mathrm{sjls} .2020 . v 05 i 09.002}$ | Received: 31.08 .2020 | Accepted: 08.09.2020 | Published: 24.09 .2020

*Corresponding author: Titus Fondo Ambebe

\section{Abstract}

Unsustainable agricultural practices pose a serious threat to the integrity of landscapes and availability of soil mineral nutrients to plants. The phenomenon is compounded by changing global climatic conditions. This paper examines the potential role of agroforestry in mitigating changes due to undesirable human behaviour in the once forest dominated western highlands of Cameroon. Data were elicited from existing literature on agroforestry, landscape management, forestry, and subsistence agriculture. Findings lend credence to the fact that agroforestry systems constitute a promising option for maintaining the stability of landscapes and soils that are subjected to human activity. Aside from the major systems namely agro-silviculture, silvo-pastoral, and agro-silvopastoral, there exist other agroforestry categories like aquaforestry, apiculture, and sericulture. Living fences, alley cropping, improved fallow, shelter belts, home gardens, and scattered trees on croplands were highlighted to be suitable agroforestry practices for the western highlands region of Cameroon.

Keywords: Agroforestry, landscape degradation, mitigation, sustainable agriculture, western Cameroon highlands.

Copyright @ 2020: This is an open-access article distributed under the terms of the Creative Commons Attribution license which permits unrestricted use, distribution, and reproduction in any medium for non-commercial use (NonCommercial, or CC-BY-NC) provided the original author and source are credited.

\section{INTRODUCTION}

Cameroon is a country with diverse ecological zones ranging from the tropical rain forest in the south west, south and eastern regions of the country, the savannah grasslands in the west, north west and Adamawa to the Sahelian zone in the north and extreme north regions [1]. Within the savannah grasslands is found the western highlands with its numerous remnants of mountain forest. The communities in this region also referred to as the "grasslanders" are subsistence farmers, nomads or hunters [2]. Recent demographic pressures, agricultural expansion, deforestation, infrastructural development and encroachments into the ruminant patches of montane and riparian forest ecosystems have led to landscape degradation with huge consequences on agricultural productivity [2]. Modern agriculture has favoured monoculture over mixed farming leading to increased deforestation and hence landscape degradation. As landscape degradation increases, so also is the likelihood of poverty among "grasslanders". There are also undesirable changes in water resources, terrestrial temperature, and food supply.
There is evidence that agroforestry can improve the standard of living of rural communities via increased agricultural productivity [3-5]. In the United States, soil erosion is estimated to cost $\$ 44$ billion a year in damage to farmland, waterways, infrastructure, and health [6]. If farmers do not ameliorate the decline in water and nutrient conditions, an $8 \%$ annual drop in crop yields is imminent [6]. The situation in the western highlands of Cameroon could be worse. A report of the Intergovernmental Panel on Climate Change (IPCC) [7] has also revealed that approximately $12-20 \%$ of global greenhouse gas emissions are caused by land-use changes and, in particular, the destruction of forest ecosystems. An appropriate land use method and sustainable forest utilization have been proposed as a cost effective way of soil fertility restoration, landscape improvement, and emissions reduction compared to other mitigation strategies such as curbing emissions from power stations and fertilizer use $[8,9]$. To protect the environment from catastrophes, levels of atmospheric greenhouse gases should be stabilized at 445-490 ppm or less, an objective that could be met with contribution from good agroforestry practices [10]. If the degradation of the environment continues undisturbed, the natural resource base will continue to 
dwindle towards an increasing unproductivity of the earth $[11,12]$.

Agroforestry refers to a land use system in which woody perennials (trees, shrubs, palms, bamboos) are grown on the same piece of land with herbaceous plants and or animals, either in a spatial arrangement or in time sequence and in which there are ecological interactions between the trees and non-tree components [13]. The integration of agriculture and forestry within a production system will solve the problems of conflicting demand for food, land for timber/ fuel wood production, drinking water and soil fertility decline fertility [3-5, 14-16].

Over the years, unsustainable human activities like urbanisation, deforestation, and animal husbandry have either directly or indirectly contributed to land degradation. Slash and burn is another problem that is rife in the western Cameroon highlands - large areas of savannah forest, wild plants and animal species are often lost in the practice [12]. Moreover, leaching, erosion, and a loss of top soil have all been tied to slash and burn. Other human activities that have been reported to cause severe environmental degradation are mineral exploitation, quarrying and the drilling of crude oil [17]. The human population has lived a rural lifestyle through most of history. The world's population, however, is quickly becoming urbanized as people migrate to the cities. Between 1950 and 2018, global urban population increased by more than fourfold, from an estimated 0.8 billion to an estimated 4.2 billion. By 2050, the population of the world is expected to be $68 \%$ urban with a population equivalence of 6.7 billion [18].Urban and rural poverty indirectly contribute to the deplorable conditions of the environment subsequently increasing atmospheric carbon dioxide concentration [19].

The removal of vegetation cover, soil erosion, deep and large mining pits, destruction of wildlife habitat, unfavourable climatic conditions and settlements around forest reserves have caused severe environmental degradation in the past [20]. Precisely, the 1970-1973 and 1981-1983 droughts which were described as Sahelian droughts adversely affected livestock production and the ecology of the Sahelian zones of sub-Saharan African countries [21]. Over 80\% of livestock rearing has resulted in soil compaction and burning of bushes for fresh vegetation [21]. The consequences on soil properties and the availability of belowground resources to crop plants could be far reaching. Massive landscape and soil degradation in the western highlands of Cameroon have been attributed to cultivation of large areas of wetlands and wilful exposure to grazing animals [12].

From the grim picture painted above on the situation of soil degradation across the world and Cameroon in particular, this study sought to examine the potential role agroforestry systems in mitigating landscape degradation and soil nutrient declines in the western highlands of the country.

\section{MATERIALS AND METHODS Study area}

Cameroon is a Central African country, covering $475,000 \mathrm{~km}$, situated between latitudes $2^{\circ}$ and $13^{\circ} \mathrm{N}$ and longitudes $8^{\circ} 30^{\prime}$ and $16^{\circ} 10^{\prime} \mathrm{E}$. This position endows the country with diversified ecological and climatic conditions, ranging from semi-desert in the north to tropical rain forest in the south. The population is 19.4 million, with an annual growth rate of $3 \%$, and a density of 34.4 persons per $\mathrm{km}^{2}$. Nearly half of the population lives in rural areas [22].

The Western Highlands of Cameroon consist of a chain of volcanic mountains stretching from the Atlantic Ocean archipelago of Soa Tome and Principe, and Bioko (Equatorial Guinea) to the mainland through Mount Cameroon (4095 m), the Rumpi Hills, the Bakossi Mountains, Mount Nlonako, the KupeMuanenguba mountains, the Bamboutos, the Bamenda Highlands containing Mount Oku (known locally as Mt Kilum) at $3011 \mathrm{~m}$ which is the second highest peak in West Africa, and North East towards the Mambila Plateau in Nigeria. The habitat ranges, with increasing altitude, from sub-montane to montane forests and ultimately subalpine grasslands. These Highlands contain the largest remaining patches of afro-montane forest in West Africa. The World Wildlife Fund has defined this area as one of its top 200 worldwide Ecoregions. The Bamenda Highlands (area: $18.100 \mathrm{~km}^{2}$, population 1.600 .000 , density: 88 per $\mathrm{km}^{2}$ ) are mixed forest and savannah grasslands with some of the highest levels of endemism in the Western Highlands. Human activities have however, increasingly fragmented, degraded and isolated remaining forest patches in the Western Highlands. By 2000, for instance, only 3.5\% remained of the $37 \%$ of forest cover that characterized the North West Region which is host to the Bamenda Highlands forest.

\section{Procedure}

The data presented in this paper were obtained from secondary sources including mainly scientific articles, dissertations, textbooks, and webpages. They were targeted on the basis of their focus on or relation to agroforestry, landscape management, forestry, and subsistence agriculture. Google Scholar was employed as the web search engine for relevant literature and when there was a hit on a suitable data source, the reference section of the document was further explored for more material. 


\section{RESULTS AND DISCUSSION}

\section{Agroforestry as a sustainable approach to mitigate} landscape and soil degradation

Certain measures need to be put in place to protect fragile and vulnerable ecosystems. The agroforestry approach could mitigate the activities of deforestation, desertification, erosion and soil fertility decline in agricultural systems [3-5, 20, 23, 24]. The forest and savannah ecosystems are pressured by agricultural encroachment, forest exploitation and urbanisation. If well practiced, the supply of food, fuelwood, construction material, water, and other ecosystem services will be met in an environmental friendly way under an agroforestry scheme $[25,26]$.

Sustainable agricultural practices can pave the way to saving fragile environments $[3,5,16]$. Owing to poor landscape management, agricultural landscapes and soils are seriously threatened by soil degradation [22]. Different forms of agroforestry can check or reduce the rate of soil, nutrient and other losses in agricultural systems [27-32].
Agroforestry systems and components for the mitigation of landscape and soil degradation

The major components of agroforestry systems are crops, trees and livestock. They can be grouped in various ways. There are, however, three key agroforestry systems namely agro-silviculture (trees and crops), silvopastroral (trees and livestock), and agrosilvopastoral (trees, crops and livestock) [5, 13, 32, 33]. Other agroforestry systems include aguaforestry (fish production with trees), apiculture (bee farming with trees), and sericulture (silk production with trees). Many other sub-systems exist. Services that trees provide are soil and undergrowth production, wind speed reduction, moderation of extreme climatic conditions, and improvement of soil fertility [4, 5, 20]. They also provide fruits, nuts, building materials and fodder $[3,31,33,34]$.

The use of any agroforestry system ensures that farmlands remain productive perpetually [3]. Most of the trees integrated in the farm fix nitrogen through root nodules as well as recycle nutrients and prevent wind and water erosion by means of their canopies and roots $(5,20]$. The green foliage from trimming/pruning or pollarding serves as green manure and improves soil nutrients conditions [23, 33]. The high annual production of litter comprising of leaves, twigs and flowers is a crucial contributor to nutrient cycling [3].

Table-1: Annual litter production from different tree species in Nigeria

\begin{tabular}{|l|l|l|}
\hline Tree species & Location & Annual litterfall (kg/ha) \\
\hline Tripolochiton scleroxylon & Gamberi & 3993 \\
\hline Tectona grandis & Ibadan & 6043 \\
\hline Pinus caribaea & Ibadan & 1875 \\
\hline Pinus caribaea & Afaka & 3665 \\
\hline
\end{tabular}

When tree species are integrated with annual crops, their litter cover on the soil surface reduces the impact of the rain drops, checks wind erosion, reduces loss of water from the soil during dry seasons and promotes soil water conservation $[3,36]$.

\section{Agroforestry practices for the mitigation of landscape and soil degradation \\ Different agroforestry practices and} technologies can be integrated into an existing farming system in order to reduce the rate of landscape and soil degradation. Six practical agroforestry practices that can be easily utilized by farmers in the western Highlands of Cameroon to combat landscape and soil degradation are discussed below:

\section{Living Fences}

These are lines of trees or shrubs planted on farm boundaries, pasture plots or around agricultural fields. Within the living fences, timber and fruits producing tree species can be planted. The trees can diversify the output of the farm such as in fruits, fodder and medicinal leaves, roots and barks [37]. Fences can improve micro-climate, soil fertility through leafs dropping, and pruning increases mulch which goes to control soil erosion.

\section{Alley Cropping}

Also known as hedgerow, alley cropping is an agro-silvicultural system in which woody plants are grown with annual crops planted in alleys in between. Its main purpose is to increase crop yield by improving soil fertility through nutrient cycling, mulching and weed control [37]. This practice is particularly important in augmenting the availability of material for a diversity of uses (e.g. poles, wood, timber, fruits, and fibre).

\section{Improved Fallow}

It is the enhancement of natural fallow grown vegetation by the introduction of selected tree species or shrubs. When crop production is alternated with a fallow period, the soil can rest and recover its fertility during the fallow period [38]. The tree species should include nitrogen fixing species such as Calliandra calothyrus, Acacia angustissima, Sesbania sesban. 
When well practiced, the system increases the production of fodder, food, fruits, fuelwood, and soil nutrient levels. For instance, improved fallow using leguminous trees has been found to increase maize yield by up to $60 \%$ [39].

\section{Shelter Belts}

Shelterbelts (or windbreaks) are plantings that provide protection from the wind and protect the soil from erosion. They are usually made up of one or more rows of trees or shrubs, planted in hedgerows around the edges of fields on farms. Other benefits of windbreaks/shelter belts include the provision of fuelwood, wildlife habitat, and creation of favourable microclimatic conditions around crop plants. Most of the trees that can be used as windbreaks are tall-growing and canopy-spreading, like Grevillea robusta, Grewia optiva, Hardwickia binala [37].

\section{Home Gardens}

This is an agro-silvicultural agroforestry practice that is carried out around dwellings. Fruit trees, woody species, vines, and palms are associated with shade tolerant agricultural species. Studies carried out by $[5,16]$ have shown that countries like Tanzania, Uganda, Ethiopia, and Kenya are characterized by multifunctional home garden agroforestry systems. Home gardening is one of the agroforestry systems which are currently being practiced in the western Cameroon highlands $[31,32]$.

\section{Scattered Trees on Croplands}

Scattered trees on croplands is another agrosilvicultural agroforestry system. Here, trees/shrubs are either planted or maintained within agricultural lands. Multipurpose are combined with agricultural crops on the same land management unit. In subSaharan Africa, the system makes use of mainly fruit trees so that fruits and fuelwood can be obtained in the process $[5,15,16]$.

\section{CONCLUSION}

The agroforestry systems described in this paper constitute a practical means of restoring fertility and protecting soils and landscapes in the western Highlands of Cameroon. Since a substantial population of the area depends on farming for livelihood, it is crucial to intensify the use of agroforestry systems to mitigate the adverse impacts of unsustainable human activities on the structure and function of ecosystems in the region.

\section{REFERENCES}

1. Neba, A. (1999). Modern Geography of the Republic of Cameroon. Neba Publishers, Bamenda, Cameroon and Camden, New Jersey, USA.

2. Tankou, C.M., de Snoo, G.R., Persoon, G., \& de Iongh, H.H. (2017). Evaluation of smallholder farming systems in the Western Highlands of
Cameroon: IOSR Journal of Engineering, 7(1), 111.

3. Jose, S. (2009). Agroforestry for ecosystem services and environmental benefits: An overview. Agroforest Systems, 76, 1-10.

4. Amare, D., Wondie, M., Mekuria, W., \& Darr, D. (2018). Agroforestry of smallholder farmers in Ethiopia: Practices and benefits. Small-scale Forestry, 18(1), 39-56.

5. Awazi, N. P., \& Tchamba, N. M. (2019). Enhancing agricultural sustainability and productivity under changing climate conditions through improved agroforestry practices in smallholder farming systems in sub-Saharan Africa. African Journal of Agricultural Research, 14(7), 379-388.

6. Kaiser, J., \& Proffitt, F. (2004). Wounding earth's fragile skin. Science, 304(5677).

7. IPCC. (2007). Climate Change 2007: Mitigation. Contribution of Working Group III to the Fourth Assessment Report of the Inter-governmental Panel on Climate Change [Metz, B., Davidson, O.R., Bosch, P.R., Dave, R., \& Meyer, L.A. (eds)], Cambridge University Press, Cambridge, United Kingdom and New York, NY, USA.

8. Butler, R. A. (2005). United States has 7th highest rate of primary forest loss. Mongabay. http://news.mongabay.com/2005/1116-

forests.html. Accessed 25.08.2020.

9. Van der werf, G. M., Morton, D. C., Defrries, R. S., Oliver, J. G. J., Kasibhatla, P. S., Jackson, R. B., Collatz, G. J., \& Randson, J. T. (2009). Carbon dioxide from forest loss. Nature Geoscience. 2, 737-738.

10. Eliasch, J. (2008). Climate change: financing global forest. Earthscan, UK.

11. Mendia, A., \& Akpan P. A. (1999). The needs for effective environmental management in Ikpa river basin of Akwa-Ibom state Nigeria. Journal of Environmental sciences, 3(1), 14-20.

12. Lambi, C. M. (2010). The environment and development frontier in sub-Saharan Africa: some global lessons. NAB Ventures, Bamenda, Cameroon.

13. Leakey, R. R. B. (1996). Definition of Agroforestry Revisited. Agroforestry Today, 8(1), 5-7.

14. Sullivan, P. (2003). Intercropping principles and production practices. Appropriate Technology Transfer for Rural Areas, Fayetteville, AR.

15. Atangana, A., Khasa, D., Chang, S., \& Degrande, A. (2013). Major agroforestry systems of the humid tropics. In Tropical Agroforestry. Springer, Dordrecht.

16. Bishaw, B., Neufeldt, H., Mowo, J., Abdelkadir, A., Muriuki, J., Dalle, G., Assefa, T., Guillozet, K., Kassa, H., Dawson, I.K., Luedeling, E., \& Mbow, C. (2013). Farmers' strategies for adapting to and mitigating climate variability and change through agroforestry in Ethiopia and Kenya, edited 
by Caryn M. Davis, Bernart, B. and Dmitriev, A. Forestry Communications Group, Oregon State University, Corvallis, Oregon.

17. Nest, E. (1992). The challenge of sustainable development in Nigeria. Nigerian Environmental Study Team.

18. United Nations, Department of Economic and Social Affairs, Population Division. (2019). World Urbanization Prospects: The 2018 Revision (ST/ESA/SER.A/420). New York: United Nations.

19. Famuyide, O. O., Adeyoju S. K., \& Akinwumi, J. A. (2000). Variabilities in the weekly household energy expenditures. The scenerio from Ijesa Zone, Osun State, Nigeria. The Journal of Ecology, 2, 17-22.

20. Mbow, C., Noordwijk, M. V., Luedeling, E., Neufeldt, H., Minang, P. A., \& Kowero, G. (2014). Agroforestry solutions to address food security and climate change challenges in Africa. Current Opinion in Environmental Sustainability, 6, 61-67.

21. Owonubi, J. J, \& Otegbeye, G. O. (2004). Disappearing forests: A review of the challenges for conservation of genetic resources and environmental management. Journal of Forestry Research and Management, 1\&2, 1-11.

22. FAO. (1990). The conservation and rehabilitation of Africa land. An international scheme towards sustainable agriculture. ARC/90/14, FAO, Rome.

23. Nair, P. K. R., \& Garrity, D. (2012). Agroforestry - The Future of Global Land Use. Advances in Agroforestry, series volume 9, edition 1, Springer Netherlands.

24. Viswanath, S., Lubina, P. A., Subbanna, S., \& Sandhya, M. C. (2018). Traditional Agroforestry Systems and Practices: A Review. Advanced Agricultural Research and Technology Journal, 2(1), 18-29.

25. Njongue, Y. N., Avana, T. M. L., Fotsing, E., \& Muderhwa, P. M. (2017). Assessing farmers' interest in Agroforestry practices around the Mount Cameroon National park (MCNP) in Cameroon. IJGPRM Second Issue.

26. Munjeb, N. L., Yerima, B. P. K., \& Avana, T. M. L. (2018). Farmer's perception of soil and watershed degradation and the assessment of soil nutrients status under agroforestry systems in the Western Highlands of Cameroon: Case of Ako sub division: Journal of Soil Science and Environmental Management, 9(8), 119-126.

27. Snelder, D. J., \& Lasco, R. D. (2008). Smallholder Tree Growing for Rural Development and
Environmental Services: Lessons from Asia. Advances in Agroforestry, Series volume 5, edition 1, Springer Netherlands.

28. Newaj, R., Chavan, S. B., \& Prasad, R. (2015). Climate-smart agriculture with special reference to agroforestry. Indian Journal of Agroforestry, 17(1), 96-108.

29. Sobola, O. O., Amadi, D. C., \& Jamala, G. Y. (2015). The role of agroforestry in environmental sustainability. IOSR Journal of Agriculture and Veterinary Science, 8(5), 20-25.

30. Negawo, J. W., \& Beyene, D. N. (2017). The role of coffee based agroforestry system in tree diversity conservation in Eastern Uganda. Journal of Landscape Ecology, 10(2), 5-18.

31. Awazi, N. P., Tchamba, N. M., \& Avana, T. M. L. (2019). Climate change resiliency choices of small-scale farmers in Cameroon: determinants and policy implications. Journal of Environmental Management, 250:109560.

32. Awazi, N. P., Tchamba, N. M., \& Temgoua, L. F. (2019). Enhancement of resilience to climate variability and change through agroforestry practices in smallholder farming systems in Cameroon. Agroforestry Systems, 88, 947-956.

33. CTA. (1996). Agroforestry, $2^{\text {nd }}$ Edition. AGROMISA, Netherlands.

34. Jerneck, A., \& Olsson, L. (2013). More than trees! Understanding the agroforestry adoption gap in subsistence agriculture: Insights from narrative walks in Kenya. Journal of Rural Studies, 32, 114-125.

35. Kedeba, O., \& Aduayi, E. A. (1986). Dry matter production and nutrient distribution in Pinus caribaea stand planted in sub-humid tropical savannah sites. Oikos, 46, 237-242.

36. Combe, J. (1982). Agroforestry techniques in tropical countries: potentials and limitations. Agroforestry Systems, 1, 13-27.

37. Nair, P. K. R. (1993). An introduction to agroforestry. Kluwer Academic Publishers, Dordrecht, Netherlands.

38. Kanmegne, J., Bayomock, L. A., Degrande, A., Asaah, E., \& Duguma, B. (2003). Establishment of Inga edulis and Calliandra calothyrus in improved fallow system in southern Cameroon. Agroforestry Systems, 58, 19-124.

39. Degrande, A., Schreckenber, K., Mbosso, C., Anegbeh, P. O., Okafor, J., \& Kanmergne, J. (2006). Farmers' fruits trees growing strategies in humid forest zones of Cameroon and Nigeria. Agroforestry Systems, 67, 159-175. 